
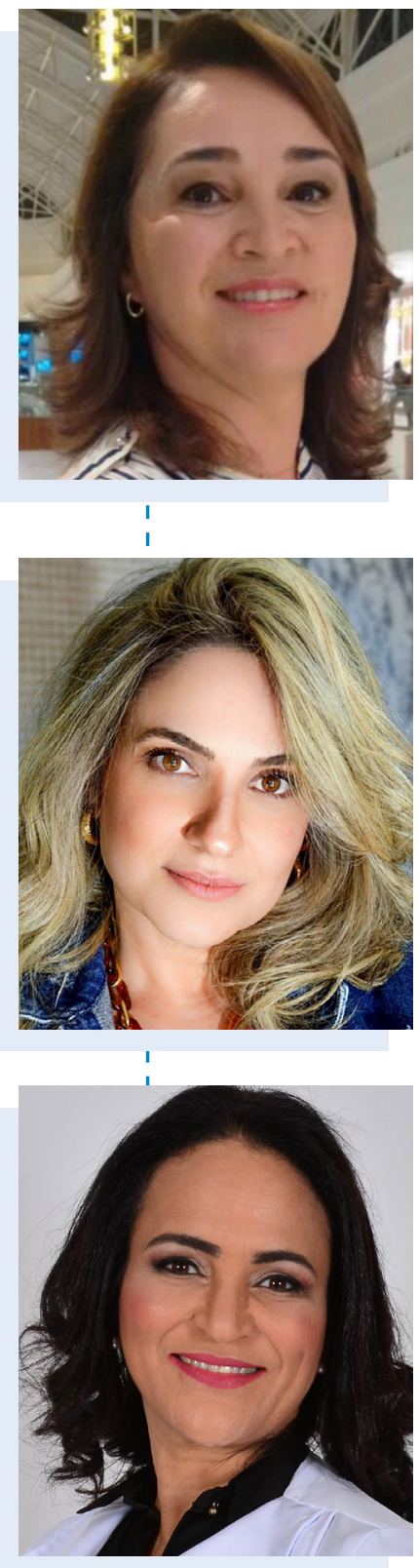

ORCID IDS

Luz GOA (D) https://orcid.org/0000-0002-2921-5078 Oliveira CR (iD https://orcid.org/0000-0003-1882-4588 Bezerra SMG (D) https://orcid.org/0000-0003-3890-5887 as the primary source for disease control.

\title{
Nursing records in face of COVID-19: contributions to nursing care, teaching, research and valorization of nursing
}

Registro de enfermagem perante a COVID-19: contribuições para assistência, ensino, pesquisa e valorização da enfermagem

\section{Registro de enfermería antes del COVID-19: contribuciones al cuidado, docencia, investigación y valorización de enfermería}

\author{
Givaneide Oliveira de Andrade Luz 1*, Carina Ribeiro de Oliveira2,4, \\ Sandra Marina Gonçalves Bezerra ${ }^{3}$
}

\section{HOW TO CITE}

Luz GOA; Oliveira CR; Bezerra SMG. Nursing records in face of COVID-19: contributions to nursing care, teaching, research and valorization of nursing. ESTIMA, Braz. J. Enterostomal Ther., 2020, 18: e3621. https://doi.org/10.30886/ estima.v18.980_IN

The advent of the internet has made it possible for people of all walks of life, ethnic groups and education levels, real time access to events anywhere in the world. Despite this, using knowledge with potential for resolution is still a major challenge that became more evident when the world was surprised by the coronavirus pandemic (COVID-19), which simultaneously isolated and connected people, bringing the urgency of information on reliable scientific evidence

In order to broaden the reflection on the theme, it is necessary, initially, to recall the origin of modern nursing through the legacy of Florence Nightingale. From her return from the Crimean War and her innovative stance, drawing on her experience and her records, she gave rise to a vast collection of data and information. Upon analyzing them, she obtained the recognition as a statistician and epidemiologist. She also demonstrated the first examples of the interconnection between research, theory and practice in nursing, which currently resembles evidence-based healthcare ${ }^{1}$.

Although Florence Nightingale was criticized for having "wasted" a lot of time writing during the chaos of the war, only this way was it possible to carry out her entire feat, resulting in the creation of nursing science and its influence in several areas of knowledge until contemporary times $^{1}$. The success of these records was due to the fact that she used the scientific method to

Universidade Federal de Pernambuco - Centro de Ciências da Saúde - Departamento de Enfermagem - Recife (PE), Brazil.

2.Faculdade Pernambucana de Saúde - Coordenação de Enfermagem - Curso de Enfermagem - Recife (PE), Brazil.

3.Universidade Estadual do Piauí - Centro de ciências da Saúde - Departamento de Enfermagem - Teresina (PI), Brazil.

4.Hospital Otávio de Freitas - Programa de Incontinência- Bexiga Neurogênica do Estado de Pernambuco - Recife (PE), Brazil.

*Corresponding author: profa.giva.oliveira@gmail.com 
record and analyze data, transform them into multidisciplinary and specific knowledge of nursing and, finally, have them published and disseminated in appropriate media ${ }^{1}$.

The current pandemic scenario is similar to that experienced by Nightingale, that is, a chaos in health care, which can be compared to a "war scenario". However, with technological structure and advanced norms that guarantee autonomy to nursing, and taxonomies with their own language and favorable to the development of records capable of leveraging the quality of care, teaching, research and the valorization of nursing.

The use of this set of tools organizes the data resulting from the observation of each patient affected by the Sars-Cov-2 virus, optimizing the appreciation and the transformation in knowledge for contiguous consumption and control of the pandemic. Undoubtedly, its application involves the epistemological dimension in the field of nursing ${ }^{2,3}$. The use of Nursing Care Systematization (NCS) is essential, because it proposes decision making by the nursing team based on a scientific method and the production of safe and reliable data and information for current and future research., ${ }^{2,4}$.

The development of scientific and technological research in Brazil takes place mainly in post graduation programs ${ }^{5,6}$. A survey with bibliometric analysis of data from the first months of the pandemic concluded that no study was found showing the nurse as the main author or even co-author, when considering national and international publications ${ }^{7}$. This suggests a focus on assistance at the expense of publication and/or a distance between Academia and service. It weighs the fact of the wealth of data and information that the nursing teams learn and that would serve or will serve as immeasurable databases for research, teaching and production of scientific evidence, if they are properly registered.

Nursing seeks social and political visibility. However, the current scenario shows that there is still a lack of knowledge and misinformation regarding the true role of nursing in the multidisciplinary health team ${ }^{8}$. Thus, in order to be recognized and valued, it is necessary to demonstrate, register, publish and disseminate technical, scientific and political articulation with proactive attitudes, especially in situations of disorder in which nursing takes the front line.

The self-confidence, self-respect and self-esteem of nursing exposed by the press have not proved to be sufficient in the face of pandemic chaos, and there is much to be done to achieve effective national and international recognition of the category $^{8}$. Despite the hard work that the class faces in the pandemic, it is essential to publish nursing information so that it can reverberate in its consolidation as a science.

In the international year of nursing, the COVID-19 pandemic represents an opportunity to write a new chapter in its history and show its value to the world. Perhaps the recognition and respect we long for are at "a pen and paper" distance, like to our matriarch Florence Nightingale, two centuries ago. Finally, we leave for reflection the following question: What story do we want posterity to know about nursing when facing Sars-Cov-2?

\section{REFERENCES}

1. Frello AT, Carraro TE. Contribuicoes de florence nightingale: uma revisao integrativa da literatura. Esc. Anna Nery 2013;17(3):573-9. https://doi.org/10.1590/S1414-81452013000300024

2. Dantas TP, Aguiar CAS, Rodrigues VRT, Silva RRG, Silva MIC, Sampaio LRL et al. Diagnósticos de enfermagem para pacientes com COVID-19. J Health NPEPS 2020;5(1): 396-416. https://doi.org/10.30681/252610104575

3. Sousa AR, Santos, GLA, Silva RS, Carvalho ESS. Reflexões sobre o processo de enfermagem no trabalho de enfermeiras frente à pandemia da Covid-19. Enferm Foco 2020;11 (1) Especial:62-7. Available at: http://biblioteca.cofen.gov.br/wp-content/ uploads/2020/08/processo-enfermagem-trabalho-pandemia-covid-19.pdf

4. Queiroz AGS, Souza RZ, Sottocornola SF, Barbosa SJ, Pinheiro FA, Souza LP. Diagnósticos de enfermagem segundo a taxonomia da NANDA internacional para sistematização da assistência de enfermagem a COVID-19. J Health Biol Sci 2020;8(1):1-6. https://doi. org/10.12662/2317-3076jhbs.v8i1.3352.p1-6.2020

5. Cunha ICKO, Erdmann AL, Balsanelli AP, Cunha CLF, Neto DL, Neto FRGX et al. Actions and strategies of schools and nursing departments of federal universities front COVID-19. Enferm foco (Brasília) 2020;11(1esp):48-57. Available at: http://revista.cofen. gov.br/index.php/enfermagem/article/view/4115/802

6. Costa R, Lino MM, Souza AlJ, Lorenzini E, Fernandes GCM, Brehmer LCF et al. Nursing teaching in covid-19 times: how to reinvent it in this context? Texto Contexto Enferm 2020;29:e20200202. https://doi.org/10.1590/1980-265X-TCE-2020-0002-0002 
7. Costa ICP, Sampaio RS, Souza FAC, Dias TKC, Costa BHS, Chaves ECL. Scientific production in online journals about the new coronavirus (Covid-19): bibliometric research. Texto Contexto Enferm 2020;29:e20200235. https://doi. org/10.1590/1980-265X-TCE-2020-0235

8. Moreira MRC, Xavier SPL, Machado LDS, Silva MRF, Machado MFAS. Enfermagem na pandemia da Covid-19: análise de reportagens à luz da teoria do reconhecimento. Enferm Foco 2020;11(1)Especial:116-23. Available at: http:// biblioteca.cofen.gov.br/wp-content/uploads/2020/09/EnfermagemPandemiaCOVID19.pdf 